\title{
GAMBARAN DOKUMENTASI ASUHAN KEPERAWATAN SPIRITUAL ISLAM BERBASIS KOMPUTER
}

\author{
Hasna Rohadatul 'Aisy' ${ }^{1}$ Dewi Mustikaningsih' ${ }^{2}$ Popy Siti Aisyah ${ }^{3}$ \\ ${ }^{1,2,3)}$ Sekolah Tinggi Ilmu Kesehatan 'Aisyiyah Bandung \\ hasnaraisy@gmail.com
}

\begin{abstract}
ABSTRAK
Dokumentasi asuhan keperawatan spiritual Islam berbasis komputer merupakan pencatatan oleh perawat secara computerized setelah melakukan asuhan keperawatan berupa pemenuhan kebutuhan spiritual pasien selama dirawat di rumah sakit. Penelitian ini bertujuan untuk menggambarkan dokumentasi pengkajian, diagnosis, perencanaan, pelaksanaan dan evaluasi keperawatan spiritual Islam berbasis komputer. Jenis penelitian ini deskriptif kuantitatif, sampel menggunakan cluster sampling, sebanyak 55 berkas rekam medis pasien. Instrumen penelitian dengan lembar observasi terdiri 17 pernyataan meliputi aspek pengkajian, diagnosis, perencanaan, pelaksanaan dan evaluasi keperawatan spiritual Islam. Hasil penelitian menunjukkan bahwa dokumentasi asuhan keperawatan spiritual Islam secara komputer untuk dokumentasi pengkajian sebagian besar terisi lengkap, dokumentasi diagnosis keperawtan belum ada, dokumentasi perencanaan keperawatan belum ada, dokumentasi pelaksanaan keperawatan setengahnya terisi dan dokumentasi evaluasi keperawatan belum ada. Simpulan dalam penelitian ini, bahwa dokumentasi pengkajian dan pelaksanaan yang banyak diisi oleh perawat, sedangkan diagnosis perencanaan dan evaluasi belum terdokumentasi dengan baik secara komputer. Rekomendasi agar bidang keperawatan membuat format dokumentasi asuhan keperawatan spiritual Islam lengkap dengan menambahkan kolom diagnosis, perencanaan dan evaluasi keperawatan secara komputer.
\end{abstract}

Kata kunci : dokumentasi asuhan keperawatan spiritual Islam, komputer, perawat

\begin{abstract}
Documentation of computer-based Islamic spiritual nursing care is a computerized nursing documentation after performing nursing care during hospitalization. This study aims to describe the documentation of the study, diagnosis, planning, implementation and evaluation of computer-based Islamic hospital in Bandung. This research used quantitative descriptive, the sample uses cluster sampling, as many as 55 patient medical record files. The research instrument with an observation sheet of 17 statements including a number divided into aspects of the assessment, diagnosis, planning, implementation and evaluation of Islamic spiritual nursing. The results showed that the computerized Islamic spiritual nursing care documentation for the assessment were mostly filled, documentation of nursing diagnoses was not available, documentation of nursing planning was lacking, documentation of nursing planning was lacking, half of the documentation of nursing implementation was filled, and the nursing evaluation documentation was not yet available. Conclusions in this study, that the documentation of the assessment and implementation are mostly filled by nurses, while the diagnosis, planning and evaluation have not been well documented in computer. Recommendations for the field of nursing to create a complete format of documentation of Islamic spiritual with used column of diagnosed, planning and evaluation of nurses based computer.
\end{abstract}

Keywords: computer,islamic spiritual nursing care documentation, nurse 


\section{PENDAHULUAN}

Keperawatan merupakan bagian lengkap dari pelayanan kesehatan yang paling lama berada disamping klien. Tugas utamanya adalah memberikan bantuan asuhan keperawatan mulai dari aspek biologis, psikologis, sosial dan spiritual. Perawat berperan untuk memenuhi kebutuhan dan kemandirian klien dalam merawat dirinya (Yusuf, 2016).

Proses keperawatan adalah suatu metode yang sistematis dan terstruktur dalam pemberian asuhan keperawatan. Proses keperawatan difokuskan pada tindakan dan tanggapan individu pada suatu kelompok atau perorangan terhadap gangguan kesehatan yang dialami, baik nyata maupun tersembunyi (Deswani, 2013). Manfaat proses keperawatan adalah metode yang sistematis, perawat bersama klien bekerja sama dalam: (1) melakukan pengkajian kebutuhan asuhan keperawatan, (2) merencanakan dan melaksanakan, (3) menilai hasil asuhan keperawatan yang berorientasikan pada klien dan tujuan.

Manfaatdokumentasiasuhan keperawatan spiritual Islam meliputi beberapa aspek, salah satunya sebagai dokumentasi pelaksanaan asuhan spiritual Islam pasien diantaranya bimbingan ibadah pasien di ruang rawat inap.

Dampak pada dokumentasi keperawatan spiritual Islam, meliputi: 1) meningkatkan mutu pelayanan keperawatan, 2) meningkatkan keterampilan teknis dan intelektual untuk pelaksana perawat, 3) meningkatkan citra keperawatan, 4) meningkatkan rasa solidaritas dan rasa kesatuan perawat, 5) menggambarkan otonom dan tanggung jawab perawat, 6) menghasilkan praktik keperawatan yang profesional, 7) mendukung pengembangan penelitian/riset, 8) mendukung pengembangan ilmu pengetahuan, 9) meningkatkan kemampuan perawat dalam pengambilan keputusan, 10) meningkatkan kepuasan kerja (Prabowo, 2017).
Dokumentasi asuhan keperawatan berbasis komputer adalah bagian dari informasi manajemen keperawatan sistem (NMIs). NMIs adalah bagian kombinasi dari komputer dalam mengembangkan ilmu pengetahuan, ilmu informasi dan ilmu keperawatan untuk mengelola dan menghubungkan informasi serta pengetahuan dalam praktek keperawatan (American Nurses Association, 2015). Penelitian dari (Hafizah, N. \& Lee, 2018) yang berjudul Nurses Perceptions, Attitudes and Preferences In Using Electronic Documentation In a Public Hospital, Selangor didapatkan hasil bahwa dokumentasi elektronik meningkatkan ketepatan melalui akses mudah ke catatan pasien dengan memastikan integritas dan keamanan data pasien melalui keaslian data dan berbagai otoritas akses. Kerugian dan salah penempatan catatan pasien, foto rontgen, yang umum terjadi dengan dokumentasi kertas dapat sangat dikurangi. Dokumentasi elektronik dapat membantu perawat dalam asuhan keperawatan. Oleh karena itu, penting untuk memastikan bahwa pelaksanaan dokumentasi elektronik memenuhi persyaratan perawatan dan tidak menghalangi komunikasi antara penyedia layanan kesehatan.

Dari penelitian (Rosyanti, 2018) didapatkan data hasil observasi dan studi dokumentasi tentang pelaksanaan asuhan spiritual pasien diantaranya bimbingan ibadah pasien di ruang rawat inap rumah sakit Islam pada periode Juni - Agustus 2018, diantaranya: hasil studi dokumentasi di 5 ruang perawatan $\mathrm{RS} \mathrm{Al}$ Islam rata-rata baru $68.8 \%$ dari yang ditargetkan dalam indikator mutu syariah sebanyak 100\%, ruangan yang paling tinggi pelaksanaan adalah Darussalam 5 dan paling rendah adalah Ruang Nuurush Shaalihaat, data tersebut secara umum masih di isi secara kuantitas kebanyakan belum sampai pada tahap membimbing pelaksanaan shalat, hanya sebatas menanyakan apakah pasien sudah shalat atau belum.

Hasil observasi didapatkan secara 
umum perawat belum melakukan bimbingan ibadah pasien saat datangnya waktu shalat (mulai dari mengingatkan shalat, membantu serta memfasilitasi wudhu atau tayamum, dan membimbing shalat), pengisian dokumentasi ada yang melakukan tetapi ada juga yang tidak melakukan, isi dokumentasinya pun hasil bertanya terhadap pasien apakah sudah shalat atau belum, bukan merupakan hasil implementasi pelaksanaan bimbingan ibadah pasien yang sudah dilakukannya.

Penelitian mengenai gambaran dokumentasi asuhan keperawatan spiritual masih belum banyak diteliti di Indonesia. Padahal, pemenuhan kebutuhan spiritual pada pasien itu perlu dilakukan. Karena selain merawat jasmani nya, perawat juga harus bisa memelihara kesehatan rohani pasien contohnya dengan selalu mengingatkan sholat, membimbing pasien berdoa, membantu pasien yang tidak mampu untuk bersuci (tayamum), membimbing pasien untuk sholat serta memfasilitasi pasien untuk sholat dan berdoa kepada Allah SWT.

Rumah sakit Islam yang berbasis syariah dengan visi menjadi rumah sakit yang unggul, terpercaya, Islami dalam pelayanan dan pendidikan serta memiliki misi melaksanakan dan menerapkan nilai-nilai Islam baik ke dalam seluruh aspek pelayanan maupun pengelolaan rumah sakit merupakan rumah sakit berbasis syariah yang berkewajiban untuk memberikan asuhan keperawatan spiritual Islam beserta dokumentasi keperawatannya. Adapun pelayanan rumah sakit terhadap pasien yaitu dengan berusaha mengelola dan melayani pasien dengan cara-cara yang halal, menjaga aurat, dan membantu tertunaikannya kewajiban ibadah bagi pasien sebagai bagian dari memelihara agama (hifzhal-din).

Peneliti melakukan studi pendahuluan ke Rumah Sakit Al-Islam Bandung bahwa dokumentasi asuhan keperawatan spiritual Islam di ruang rawat inap sudah menggunakan komputer tetapi yang terdapat di dalam komputer hanya di implementasi yaitu bagian edukasi pasien yang terkait dengan bina rohani dan edukasi pasien pulang disertai pesan agama. Sebagian ada yang masih berbasis manual terkait pelaksanaan ibadah yaitu: thaharah, tadzkirah (mengingatkan waktu sholat) dan pelaksanaan sholat. Untuk dokumentasi asuhan keperawatan spiritual islam (dari pengkajian sampai evaluasi) masih berbasis manual.

\section{METODOLOGI}

Jenis penelitian yang digunakan yaitu deskriptif eksploratif yang bertujuan untuk menggambarkan keadaan suatu fenomena. Penelitian ini tidak dimaksudkan untuk menguji hipotesis tertentu tetapi hanya menggambarkan apa adanya suatu variabel, gejala atau keadaan (Nursalam, 2015). Teknik sampling yang digunakan yaitu cluster sampling dengan jumlah 55 berkas. Hasil yang didapatkan dari uji validitas yaitu 0,641 - 0,748 dan KR-20 0,852.

Instrumen yang digunakan dalam penelitian ini adalah lembar observasi yang dibuat sendiri oleh peneliti karena peneliti ingin mengetahui kualitas pendokumentasian asuhan keperawatan spiritual Islam dengan cara melihat berkas status rekam medis pasien secara komputer lalu dicatat kelengkapannya. Lembar observasi ini terdiri dari 17 item pernyataan.yang berupa tabel dokumentasi pengkajian, diagnosis keperawatan, perencanaan, implementasi dan evaluasi yang pengisiannya memakai skala guttman yaitu nilai 1 bila dokumentasi lengkap dan nilai 0 bila dokumentasi tidak lengkap dan terdapat kolom keterangan untuk menuliskan item yang belum ada di dokumentasi keperawatan spiritual Islam secara komputer.

Lembar observasi ini dilakukan uji validitas pada tanggal 4 Juli 2019 pada 30 berkas rekam medis pasien di ruang rawat inap lain. Hasil uji validitas lembar observasi dokumentasi asuhan 
keperawatan spiritual dari 18 item didapatkan 13 item yang valid ( $p>0,463)$, yaitu item no $5,6,7$, $8,9,10,11,12,13,14,15,16,17$. Item yang tidak valid pada lembar observasi dokumentasi asuhan keperawatan spiritual dihilangkan dan diubah redaksi kalimatnya.

Dari hasil uji validitas lembar observasi, peneliti menggunakan 17 item pertanyaan untuk penelitian ini dengan membuang 1 item pertanyaan serta mengubah 3 item pertanyaan lainnya yang berkaitan dengan studi dokumentasi asuhan keperawatan spiritual Islam. Untuk uji reliabilitas pada lembar observasi yang berskala Guttman ini menggunakan rumus KR-20. Hasil uji reliabilitas untuk lembar observasi dokumentasi asuhan keperawatan spiritual yang digunakan untuk penelitian didapatkan reliabilitas 0,852 maka dapat dinyatakan reliabel $(p>0,6)$.

Untuk menentukan besarnya sampel pada setiap ruangan dilakukan dengan alokasi proporsional (Sugiyono, 2017).

Jumlah sampel tiap ruangan $=$ $\frac{\text { jumlah sampel }}{\text { jumlah populasi }} x$ jumlah tiap ruangan

Pengumpulan data dilakukan dengan mengisi lembar observasi. Tahapan yang dilakukan adalah membuat surat perizinan melalui pihak akademik STIKes 'Aisyiyah Bandung untuk melakukan penelitian di Rumah Sakit AlIslam Bandung, kemudian peneliti memberikan surat perijinan penelitian kepada bagian umum Rumah Sakit Al-Islam Bandung yang ditujukan kepada diklat keperawatan Rumah Sakit AlIslam Bandung. Setelah mendapatkan perijinan dari diklat keperawatan Rumah Sakit Al-Islam Bandung, kemudian penjelasan tujuan kepada Kepala Bidang Keperawatan lalu peneliti siap untuk melakukan penelitian.

Prosedur yang dilaksanakan saat penelitian yaitu informed consent dan pengisian lembar observasi. Pengerjaan lembar observasi dengan melihat berkas rekam medis pasien didalam komputer yang berada di Ruangan Darussalam 3, Darussalam 4 dan Darussalam 5. Total 17 item pernyataan ini menjabarkan 5 proses keperawatan yaitu dari pengkajian, diagnosis, intervensi, implementasi dan evaluasi keperawatan spiritual.

Analisis yang digunakan yaitu univariat untuk menilai pengkajian, diagnosis, intervensi, implementasi dan evaluas keperawatan spiritual pada rekam medis pasien. Skala jawaban kuantitas yang dicantumkan adalah $<50$ untuk kurang, 51 - 75 untuk cukup, 76 -100 untuk baik. Lembar observasi berjumlah 17 item pernyataan, dengan 5 proses keperawatan dan hasil akhir yaitu dokumentasi asuhan keperawatan spiritual baik, cukup atau kurang. Kemudian data dihitung dengan distribusi frekuensi, persentase, dan ratarata.

Untuk keterangan kualitatif yang tercantum pada lembar observasi itu diisi dengan narasi jika perawat telah mendokumentasikan sesuai pengkajian, diagnosis, intervensi, implementasi dan evaluasi keperawatan spiritual.

Etika penelitian yang digunakan dalam penelitian ini adalah inform consent, anonimity, kerahasiaan, beneficien. Penelitian ini telah mendapatkan persetujuan Komite Etik Penelitian STIKes 'Aisyiyah Bandung nomor 11/KEP.02/ STIKes-AB/VI/2019. Dan komite etik penelitian RSAI Bandung dengan nomor 0005/KEPKRSAI/06/2019.

\section{HASIL}

Berikut merupakan distribusi frekuensi dokumentasi asuhan keperawatan spiritual Islam berbasis secara kuantitas. 
Tabel 1. Distribusi Frekuensi Dokumentasi Asuhan Keperawatan Spiritual Islam berbasis komputer secara kuantitas $(n=55)$

\begin{tabular}{|c|c|c|c|c|c|c|}
\hline \multirow{4}{*}{ Variabel } & \multicolumn{6}{|c|}{$\begin{array}{c}\text { Ruangan Darussalam 3, Darussalam } 4 \text { dan } \\
\text { Darussalam } 5\end{array}$} \\
\hline & \multicolumn{6}{|c|}{ Hasil } \\
\hline & \multicolumn{2}{|c|}{ Baik } & \multicolumn{2}{|c|}{ Cukup } & \multicolumn{2}{|c|}{ Kurang } \\
\hline & $\mathbf{N}$ & $\%$ & $\mathbf{N}$ & $\%$ & $\mathbf{N}$ & $\%$ \\
\hline Pengkajian keperawatan spiritual & 53 & $93,0 \%$ & 34 & $59,6 \%$ & 13 & $7,15 \%$ \\
\hline Diagnosa keperawatan spiritual & 0 & $0 \%$ & 0 & $0 \%$ & 100 & $100 \%$ \\
\hline Intervensi keperawatan spiritual & 0 & $0 \%$ & 0 & $0 \%$ & 100 & $100 \%$ \\
\hline Implementasi keperawatan spiritual & 0 & $0 \%$ & 38 & $66,7 \%$ & 24 & $42,1 \%$ \\
\hline Evaluasi keperawatan spiritual & 0 & $0 \%$ & 0 & $0 \%$ & 100 & $100 \%$ \\
\hline
\end{tabular}

Tabel 1 di atas menunjukkan distribusi frekuensi dokumentasi asuhan keperawatan spiritual Islam berbasis komputer secara kuantitas pada rekam medis pasien di ruangan Darussalam 3, 4 dan 5. Untuk dokumentasi pengkajian keperawatan spiritual Islam termasuk kategori baik sebesar (93,0\%), kategori cukup sebesar $(59,6 \%)$ dan kategori kurang sebesar $(7,15 \%)$. Untuk dokumentasi diagnosis keperawatan spiritual Islam termasuk kategori kurang sebesar (100\%), untuk dokumentasi intervensi keperawatan spiritual Islam termasuk kategori kurang sebesar (100\%), untuk dokumentasi implementasi keperawatan spiritual Islam termasuk kategori cukup sebesar (66,7\%) dan kategori kurang sebesar (42,1\%), untuk dokumentasi evaluasi keperawatan spiritual islam termasuk kategori kurang sebesar (100\%).

\section{PEMBAHASAN}

Berdasarkan hasil penelitian didapatkan bahwa sebagian besar dokumentasi asuhan keperawatan spiritual Islam dalam prosesnya memiliki kategori kurang karena tidak ada lembar/format untuk diagnosis, intervensi dan evaluasi. Kategori kurang menunjukkan bahwa dokumentasi asuhan keperawatan spiritual Islam belum terdokumentasikan secara lengkap.

Dalam melakukan pelaksanaan dokumentasi pengkajian keperawatan spiritual sebenarnya perawat telah mengisi dalam format ceklis yang sudah tersedia didalam komputer termasuk kategori baik sebesar (93\%). Karena sudah sesuai dengan Standar Asuhan Keperawatan Spiritual di Rumah Sakit Islam Bandung tercantum bahwa pengkajian keperawatan spiritual meliputi aspek agama Islam, penggunaan kerudung untuk pasien perempuan, kemampuan pasien untuk bersuci, pelaksanaan sholat, kendala tidak sholat dan keyakinan tentang penyakit.

Adapun secara kualitas ada aspek konsep ketuhanan belum terkaji dalam format yang disediakan. Konsep ketuhanan meliputi perasaan terhadap Allah Subhanahu wa ta'ala saat ditimpa sakit, makna hidup serta sumber kekuatan dan harapan (Inggriane, 2016a).

Dalam melakukan dokumentasi diagnosis keperawatan spiritual sebenarnya tidak ada lembar diagnosis spiritual, tetapi pada Standar Asuhan Keperawatan Spiritual di Rumah Sakit Islam Bandung tercantum bahwa diagnosis keperawatan spiritual meliputi distress spiritual dan risiko distress spiritual. Adapun secara kualitas ada diagnosis yang belum terkaji dalam format yang disediakan, seperti: kurang pengetahuan tentang pelaksanaan ibadah, gangguan praktik ibadah, kesiapan untuk peningkatan praktik ibadah, risiko gangguan praktik ibadah dan 
kesiapan untuk peningkatan kesejahteraan spiritual (Inggriane, 2016a).

Dalam melakukan dokumentasi intervensi keperawatan spiritual sebenarnya tidak ada lembar intervensi dalam catatan keperawatan, tetapi pada Standar Asuhan Keperawatan Spiritual di Rumah Sakit Islam Bandung tercantum bahwa intervensi keperawatan spiritual meliputi dukungan spiritual dan fasilitasi pengembangan spiritual.

Adapun secara kualitas perawat ingin membantu pasien untuk mencapai hasil yang diharapkan yang belum terkaji dalam format yang disediakan yang meliputi pengkajian pengetahuan pasien tentang praktik ibadah pada orang sakit,pengkajian kegiatan ibadah ritual pasien, konseling yang pernah dilakukan oleh pasien, pengkajian klarifikasi nilai pasien, pengkajian dukungan emosi pasien, pengkajian dukungan kelompok, pengkajian peningkatan harapan pasiendan pengkajian dying care (Inggriane, 2016a).

Dalam melakukan pelaksanaan dokumentasi implementasi keperawatan spiritual sebenarnya perawat telah mengisi dalam format ceklis yang sudah tersedia didalam komputer yang berada di catatan terintegrasi perawat, dan sesuai pada Standar Asuhan Keperawatan Spiritual di Rumah Sakit Islam Bandung tercantum bahwa implementasi keperawatan meliputi kolom mengingatkan sholat dan membimbing pasien berdoa.

Adapun secara kualitas bahwa perawat siap melaksanakan intervensi yang belum terkaji dalam format yang disediakan, seperti: selalu mengucap salam pada klien/keluarga, selalu mengawali setiap kegiatan dengan basmallah, selalu mengajak pasien berdoa setiap akan melakukan tindakan, selalu mengawali kegiatan operan jaga dengan berdoa bersama, selalu mengingatkan waktu sholat kepada pasien, membantu pasien yang tidak mampu melakukan thaharah (bersuci dengan menggunakan debu/ tanah) dan membimbing pasien sholat (Inggriane, 2016a).

Dalam melakukan pelaksanaan dokumentasi evaluasi keperawatan spiritual belum ada lembar evaluasi keperawatan seperti SOAP dalam catatan keperawatannya,dan didokumentasikan evaluasi dariupaya pemenuhan kebutuhan dasar manusia dari aspek spiritualitas islam. Serta evaluasi keperawatan secara kualitas yang ingin dicapai adalah adanya peningkatan pengetahuan tentang praktik ibadah pada orang sakit, peningkatan praktik ibadah ritual, memiliki keterampilan interaksi sosial yang baik, stabilitas emosi, memiliki harapan, kesejahteraan spiritual, hidup yang berkualitas dan mencapai kematian yang khusnul khatimah (Inggriane, 2016b).

\section{SIMPULAN DAN SARAN}

Berdasarkan hasil penelitian mengenai gambaran dokumentasi asuhan keperawatan spiritual Islam Berbasis Komputer didapatkan hasil bahwa sebagian besar dokumentasi asuhan keperawatan spiritual Islam masih kurang baik. karena belum ada lembar/format diagnosis, intervensi dan evaluasi dalam catatan keperawatannya. Disarankan untuk Rumah Sakit untuk diadakan penyesuaian format dokumentasi asuhan keperawatan spiritual islam yang komprehensif. Dilihat dari kualitas dokumentasi asuhan keperawatan spiritual islam belum terdokumentasi secara utuh, karena perawat bukan tidak mendokumentasikan secara kompter tetapi karena tidak ada format untuk dokumentasi diagnosis, intervensi, evaluasi secara komputer dan dokumentasi implementasi juga perlu ditambahkan sesuai perencanaan kebutuhan spiritual islam

\section{DAFTAR PUSTAKA}

American Nurses Association. (2015). ANA's principles for nursing documentation: 
guidance for registered nurses. Silver Spring, MD: ANA, Nursebooks.

Deswani. (2013). Proses Keperawatan dan Berpikir Kritis. Jakarta: Salemba Medika.

Hafizah, N. \& Lee, K. (2018). Nurses'perceptions, Attitudes And Preferences In Using Electronic Documentation In a Public Hospital, Selangor. International Journal of Public Health and Clinical Sciences, 5(6), 307-318.

Inggriane, P. D. (2016a). Modul Asuhan Keperawatan Spiritual Muslim 2. Bandung: Sekolah Tinggi Ilmu Kesehatan 'Aisyiyah Bandung.

Inggriane, P. D. (2016b). Qur'anic Therapy. In Monograf (1st ed.). Bandung: Sekolah Tinggi Ilmu Kesehatan 'Aisyiyah Bandung.
Nursalam, M. (2015). Metodologi Penelitian Ilmu Keperawatan Edisi ke-4. Jakarta: Penerbit Salemba Medika.

Prabowo, T. (2017). Dokumentasi Keperawatan. Yogyakarta: Pustaka Baru Press.

Rosyanti. (2018). Gambaran Kompetensi Perawatan Spiritual Pada Perawat Pelaksana Di Ruang Rawat Inap Rumah Sakit Al-Islam Bandung. Sekolah Tinggi Ilmu Kesehatan 'Aisyiyah Bandung.

Sugiyono, P. D. (2017). Metode Penelitian Bisnis: Pendekatan Kuantitatif, Kualitatif, Kombinasi, dan R\&D. Penerbit CV. Alfabeta: Bandung.

Yusuf, D. (2016). Kebutuhan spiritual: konsep dan aplikasi dalam asuhan keperawatan. Buku Referensi. Mitra Wacana Media. 
